\title{
MODERN LANDSCAPES OF THE KERCH PENINSULA
}

\author{
I'rof. Dr. Ekaterina POZACHENYUK' \\ I'rof. Dr. Fedor LISETSKII² \\ Ass. Prof., Ph.D Irina KALINCHUK ${ }^{1}$ \\ Student Albina ASANOVA ${ }^{1}$ \\ Ass. Prof., Ph.D Ignat IGNATENKO ${ }^{3}$ \\ Crimean Federal V.I. Vernadsky University, Tavrida Academy (structural subdivision), \\ Simferopol - Russian Federation \\ ${ }^{2}$ Belgorod State National Research University, Federal and regional centre for aerospace and \\ surface monitoring of the objects and natural resources, Belgorod - Russian Federation \\ 'Belgorod State National Research University, Institute of Earth Sciences, Belgorod - Russian \\ Federation
}

\begin{abstract}
The characteristic of modern landscapes of the Kerch Peninsula as geologic systems in which natural and economic subsystems are inseparably connected is presented in the article. The component structure of the landscapes of the Kerch Peninsula (geological structure, relief, climate, water, soil, flora and fauna) was analysed using constructed thematic maps. The complex structure of the landscapes of the Peninsula is presented, with the indication of landscape levels, landscape zones, landscape areas. The description of the modern economy of the Kerch Peninsula as an economic subsystem has been completed. The modern landscapes of the Peninsula show varying degrees of integration of natural and economic components. This can be shown by overlaying the maps of the natural and economic subsystems. The maps of the natural and economic subsystems, and of the modern landscapes of the Kerch Peninsula, are provided in the work. It is shown that the map of modern landscapes can be used in territorial planning, including landscape planning. This cartographic model can be used as a basis for integrated assessments of territorial differences and evaluation maps.
\end{abstract}

Keywords: modern landscapes, natural and economic subsystems, cartographic model.

\section{INTRODUCTION}

The Kerch Peninsula landscapes under new economic development conditions, not least because of logistical changes in the transport system of the Crimea, are experiencing intense anthropogenic loads. Due to the unique character and diversity of the peninsula landscapes, along with their intensive transformation, it becomes actual to study the present-day landscapes as a single geosystem, which however consists of natural and economic subsystems. One can hardly imagine the present-day landscapes without natural and economic components being united. This is especially true for areas with a long history of human activity. In the period of antiquity, the Bosporan Kingdom included territory of the Eastern Crimea [1], and the economy of this state was based on 
agriculture, particularly, the cultivation of bread crops. In ancient times landscape anthropogenic transformation $(6 \mathrm{c} . \mathrm{BC}-4 \mathrm{c}$. AD) used to increase from the western part of Kerch Peninsula (up to the modern Uzunlar rampart) towards its eastern part (from rampart to Pantikapaion - capitals of Bosporus Kingdom) [2]. High farming standarda ensuring the sustainable use of the soil resources were established on the chora of a number of ancient centres [3], while the agricultural development of the region wis synchronous with the increase in the thickness of the humus horizons $[4,5]$. This study aims to develop a research approach for the present-day landscapes as an inseparable unity of natural and economic subsystems acting (on the example of Kerch Peninsulu) as a geosystem to using GIS- mapping methods.

\section{DATA AND METHODS.}

The study was based on a group of the following methods: field landscape mapping, landscape-ecological investigations on the key sites and methods of remote sensing data analysis (including computer interpretation of satellite images), mathematical and cartographic modelling and mapping. The paper uses digital satellite images of different spatial resolution for the period from 2010 to 2017 (multispectral satellite images from Landsat 8OLI satellites and images obtained from a public non-commercial archive on the Internet on the site http://glovis.usgs.gov (EarthResourcesObservationandScience Center (EROS), U.S. Department of the Interior, U.S. Geological Survey). Highresolution satellite images of Quick Bird $(2.44 \mathrm{M} /$ pixel) have been used for detailed investigations at the local level.

\section{RESULTS AND DISCUSSION}

Kerch Peninsula is located in the eastern part of the Crimea Peninsula washed by the Azov Sea in the north, by the Kerch Strait in the east and by the Black Sea in the south. The length of the peninsula from west to east is about $90 \mathrm{~km}$, from north to south from 17 to $50 \mathrm{~km}$, the area is $2700 \mathrm{~km}^{2}$. The tectonics of the region is largely determined by its border location among the Crimean and Caucasus Mountains, the Black Sea basin and the Scythian platform which is reflected in the presence of earthquakes [6] and mud volcanoes [7]. The present-day Kerch Peninsula landscapes are represented by natural and economic subsystems. The natural subsystem is characterized by landscape's component and complex structure.

Component landscape structure of Kerch Peninsula. Kerch Peninsula is a part of the Kerch-Taman folded area. which determined its complex geological structure. Its territory is solely covered by sedimentary rocks, which are aged from Upper Cretaceous to Quaternary period and at least $5 \mathrm{~km}$ thick. Deposits of the so-called Maikop series clay with occasional interlayers of sands and sandstones, and with the thickness of up to $3000 \mathrm{~m}$ - are most widely spread. Limestones, shell deposits and Neocene clays underlay in the Maikop clays in the northern and eastern parts of the peninsula. The deposits formed in the Cimmerian age of the Neocene period hold a unique position among the Kerch Peninsula sedimentary rocks. These deposits are represented by iron ores, which unlike most of the world's deposits, are of sedimentary rather than magmatic origin.

The Kerch Peninsula relief is flat, undulating and ridged; it is of erosion and denudation type. The territory largely has slight land surface slopes (Figure 1). As for terrain, the peninsula is nominally divided into two parts, which are inter-separated by the Parpach 
Kidge. The southern and western parts of the peninsula are represented by an undulating mnd monotonous plain with rare hills composed of Maikop clays. In the north, east and mortheast the peninsula terrain is complicated by high hills and ridges formed by Nocene limestone.

Ihe climate of the territory of Kerch Peninsula is dry, moderately hot, of the continental lype (the spring is cool, the summer is moderately hot, the winter is mild, the autumn is warm). Average air temperature in the warmest month (July) $26^{\circ} \mathrm{C}$, in the coldest month (liebruary) $-4^{\circ} \mathrm{C}$, and for the year $11^{\circ} \mathrm{C}$. Annual precipitation ranges from $340-440 \mathrm{~mm}$, with a maximum in summer. More precipitation falls in the northeastern part of the peninsula.

Rivers and ravines represent the Kerch Peninsula surface watercourses. The low water content of the peninsula surface-stream flows is caused by small amounts of precipitation (about $400 \mathrm{~mm}$ per year). During winter and spring, it is typical to have lloods. The average intensity of river water rise level is $0.1-0.2 \mathrm{~m} /$ day (March - April, or in June) in spring with maximum of $0.5 \mathrm{~m} /$ day. In summer, surface runoff is mainly maintained by springs. Autumn and winter floods are mild; sometimes they can be in December - January. The problem of water resources is aggravated by water shutoff in the North Crimean Canal. However, in 2014 a hydroelectric complex was built on the Biyuk-Karasu river, which redirected the river flow to the North Crimean Canal in order to ensure water supply to the urban population Sudak, Feodosia, Kerch and the territory of Kerch Peninsula.

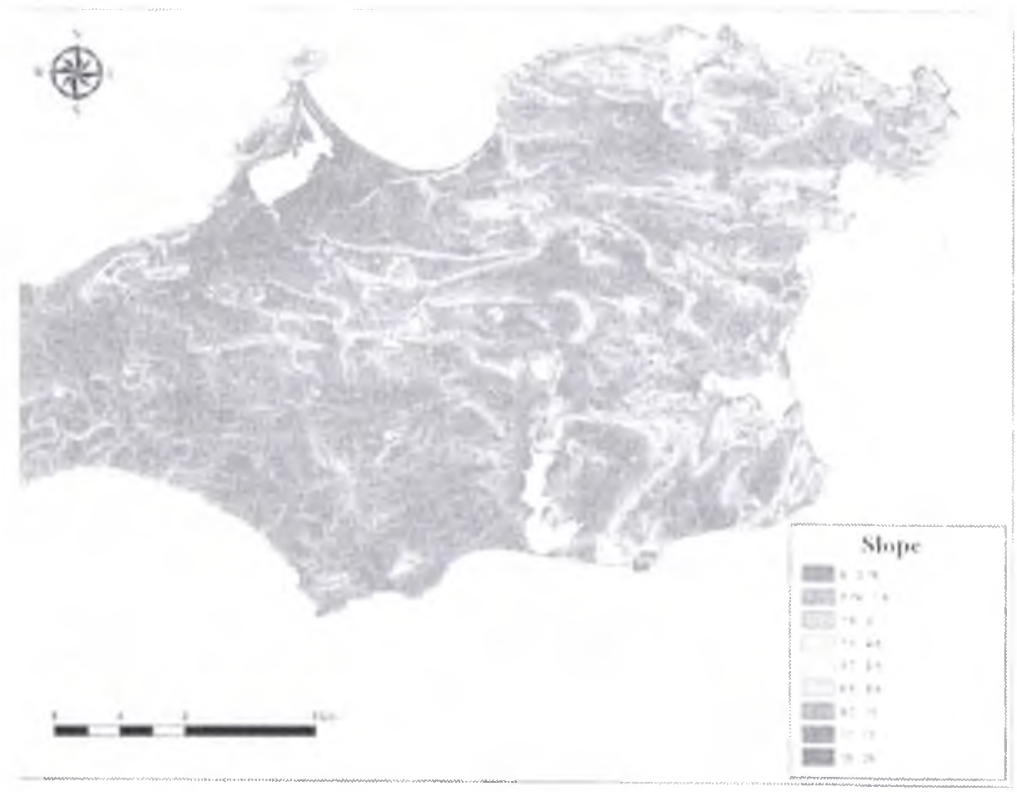

Figure 1. Slopes of the surface of the Kerch Peninsula

The main types of soils which form the Kerch Peninsula soil cover include southern, carbonate and alkaline chernozems, dark chestnut alkali soils, solonetzic and solonchak soils. The soil cover complexity is determined by the relief, lithological structure and hydrological terrain conditions [8]. The natural salinity of the Maikop clays results in weak salination of related soils.

The flora of the Kerch Peninsula is quite diverse and has 1068 species. Such families represent flora as Asteaceae, Poaceae, Fabacear, Brassicaceae, Lamiacae, 
Caryophyllaceae, Apiaceae, Rosaceae, Boraginaceae, Chenopodiaceae and others According to [9], the flora of the peninsula can be ranked as follows: polycarpic herbs (33.62\%); annual species $(27.93 \%)$; winter crops $(21.55 \%)$; spring crops $(6.10 \%)$; dwurl semishrub (4.4\%); shrubs (1.87\%); half shrub $(0.75 \%)$; trees $(0.66 \%)$; subshrul $(0.28 \%)$; others $(2.84 \%)$. The peninsula flora has some Mediterranean features, and it is ruderal with annual species being widely spread, which goes to prove the increasiny influence of the anthropogenic factor. The main representatives of the flora of the Kerch region are Stipa capillata, Stipa lessingiana, Festuca rupicola, Agropyron pectiniforme, Koeleria cristata, Poa bulbosa var. Vivipara and others. In some areas, you can see various salt-tolerant plants in particular Salicornia and Halocnemum [10].

The Kerch Peninsula vegetation cover very multi-coloured. Due to the variable terrain and rock properties, it combines various variations of steppe vegetation. Halophytic meadows are widespread on the south-western plain with shallow saline groundwater while meadow steppes are prevailing in the east of the peninsula. Desert steppes are alternated with sheep fescue and feather ones in the north of the peninsula. Some scrubs that were earlier much more widespread are preserved on ridge slopes, in gullies, in hollows and on cliffy seashores [11]. Among the shrubs most common: Rosa, Prunus spinosa, Sambucus, Laburnum and others. From trees - Acacia, Elaeagnus commutata, Rhámnus and others. Special climatic and ecological conditions tend to be formed in coastal areas, which is reflected on biodiversity. Due to the highly dry climate, the coastal vegetation lacks moisture and it is therefore sparse.

The fauna of the Kerch Peninsula is diverse in reptiles (Podarcis tauricus and Lacerto agilis, Natrix natrix, Pseudopus apodus and others). Among mammals Mustela eversmanni, Mustela, Erinaceus, Sicista subtilis, Arvicola amphibius, Crocidura suaveolens, Lepus europaeus, Spermophilus pygmaeus, Mus musculus, Mus spicilegus, Cricetulus migratorius, Microtus socialis, Vulpes vulpes, Mustela and others are widely distributed. The world of birds is quite rich, especially waterfowl - Larus argentatus, Phalacrocorax, Anas platyrhynchos, Ardea cinerea; meet Plegadis falcinellus, Aquila chrysaetos, Aquila pennata, Circus cyaneus and Circus macrourus, Falco peregrinus, Falco cherrug, Grus grus, Numenius arquata, Lanius senator, Emberiza melanocephala, Sturnus roseus and others [8].

Complex structure of landscapes by Kerch Peninsula. The Kerch Peninsula landscapes were formed within two landscape levels: hydromorphic and upland [12, 13]. Each landscape level has its own characteristics (Table). There is a marked area of low-lying and low-drained plains with halophytic meadows and steppes within the hydromorphic level. An area of typical poor grassland steppes is represented on the upland plains (Figure 2).

Table. Landscape levels of the Kerch Peninsula

\begin{tabular}{|c|c|c|c|c|}
\hline $\begin{array}{c}\text { Landscape } \\
\text { levels }\end{array}$ & Natural areas & $\begin{array}{c}\text { Height, } \\
\text { m a.s.l. }\end{array}$ & $\begin{array}{c}\text { Annual } \\
\text { precipitation, mm }\end{array}$ & $\begin{array}{c}\text { Moisture } \\
\text { ratio, \% }\end{array}$ \\
\hline Hydromorphic & $\begin{array}{c}\text { semidesertic vermuth- } \\
\text { fescue steppes }\end{array}$ & $0-40$ & $300-400$ & $0.32-0.38$ \\
\hline Upland & $\begin{array}{c}\text { typical poor grassland } \\
\text { fescue-feather grass steppes }\end{array}$ & $40-150$ & $360-400$ & $0.34-0.47$ \\
\hline
\end{tabular}




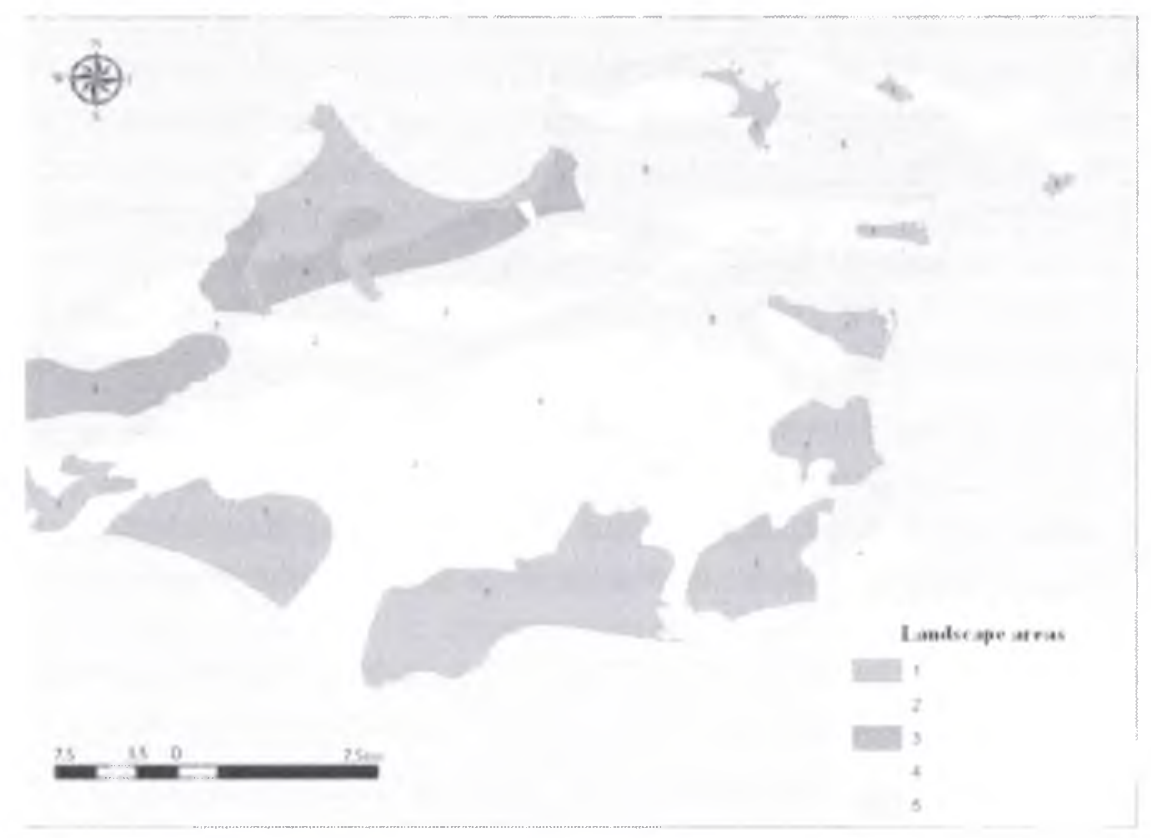

Figure 2. The natural subsystem of modern landscapes of Kerch Peninsula

Zone of lowland undrained and weakly drained plains with halophytic meadows and steppes:

I. Coastal undrained lowlands, beaches and braids on quaternary deposits, with salt marshes and saline soils under halophytic meadows, salt marshes and psammophyte communities;

2. Non- and low-drained lowlands on quaternary deposits, with meadow-calcareous saline soils under semiarid steppes in a complex with halophytic;

3. Low-drained plains on quaternary loesslike-loamy deposits with dark chestnut soils, including solonets, with semidesertic steppes in combination with poor grassland.

\section{Zone of typical poor grassland steppes on upland plains:}

4. Abrasion-outwash plains on Miocene-Pliocene limestone and clays with chernozem merged solonetzic and solonets under fescue-feather grass and petrophytous steppes and shrubby grassland steppes;

5. Gently dipping accumulative-outwash plains on loesslike-loamy deposits with chernozem southern and chernozem merged solonetzic under fescue-feather grass and feather-grassland steppes.

Economic subsystem of modern landscapes of Kerch Peninsula. Kerch Peninsula is an eastern economic micro-district, which structurally includes the Leninsky district and Kerch (land urban district). The micro-district has an advantageous transport and geographical position as it is located at the intersection of land and sea routes of the Crimean and Taman Peninsula. Kerch has become a hub of transportation links of the Republic of Crimea with the mainland of Russia. The main types of economic activity in the region include agriculture, transport, industry, recreation, commercial and sport fishing, hunting, preparation of medicinal raw materials. Its economic activity is mainly focused on the agroindustrial complex, which employs about a third of the population. The agricultural industry is mainly oriented on pastoral livestock (developed dairy cattle, growing pigs and sheep). The following is of subordinate importance: crop production (main crops: wheat, barley, peas), collection of medicinal herbs, fodder conservation and mowing of wormwood and other essential-oil plants. In general, 84 enterprises are involved in the agricultural activities of the peninsula. 
Gas (East-Kazantipskoe and North-Bulganakskoe deposits) and oil (Semenovskoe deposits) are extracted on the peninsula shelf. The largest enterprises of the peninsulin include a concrete plant, a canning plant "Arctica" and a vintage cognac factory "Alel. Vinal"'. Kerch develops shipbuilding, ship repair, fishing and processing of fish resources. The transport sector is widely developed (Kerch Sea Trade Port and Crimen Bridge). The main branch of the Kerch economy is focused on shipbuilding and ship repair works (factory "Zaliv", wharves "Fregat" and "Tral"). The shipbuilding products include passenger ships, tugs, ferries and tankers.

A complex environmental management system with the following main types has currently formed in the Kerch Peninsula area: agricultural, residential, road transport, aquicultural, industrial and forestry (Figure 3). The priority development areas include reforming of health resort and tourism sector of the economy, modernization of industry sectoral structure, transport potential development, educational system modernization, housing and utility development, etc. It is expected that the human activity will be increased in the near future [14].

The present-day Kerch Peninsula landscapes represent entities, which differ in different degree of integrity of natural and economic components, which can be cartographically reflected by the two-map overlap method for natural and economic subsystems (Fig. 4).
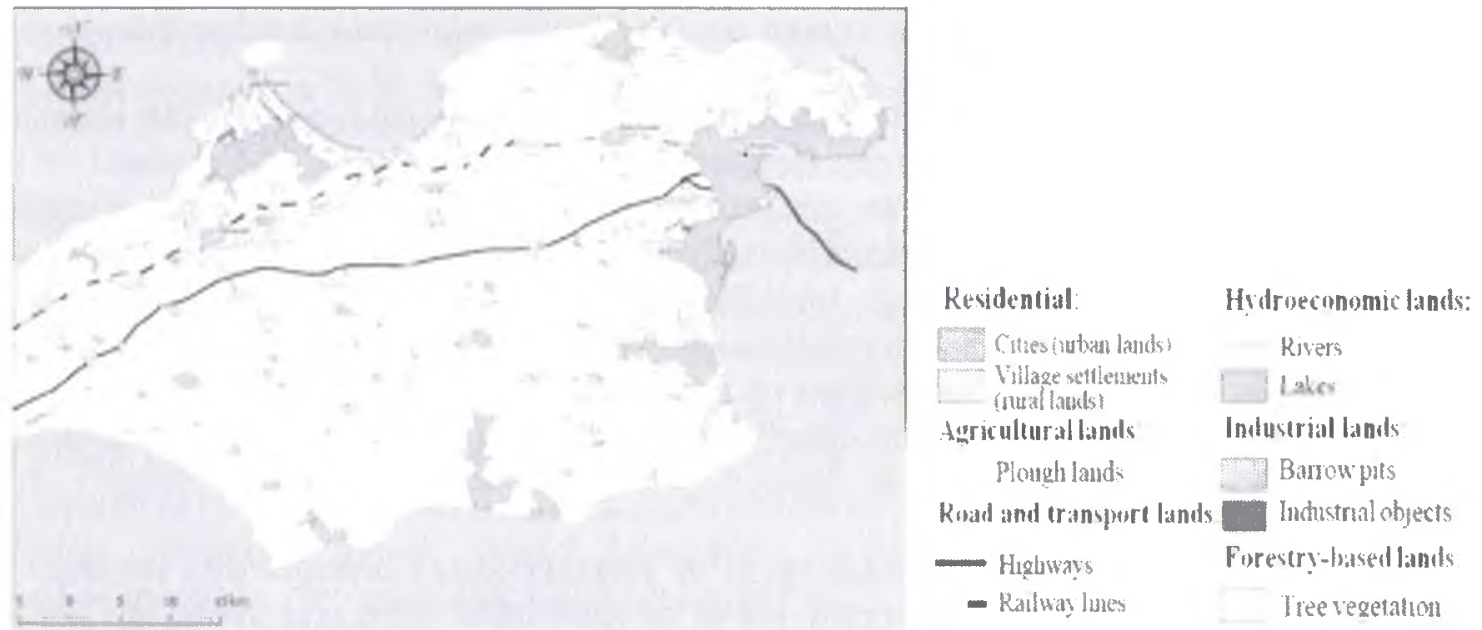

Figure 3. Economic subsystem of modern landscapes of Kerch Peninsula
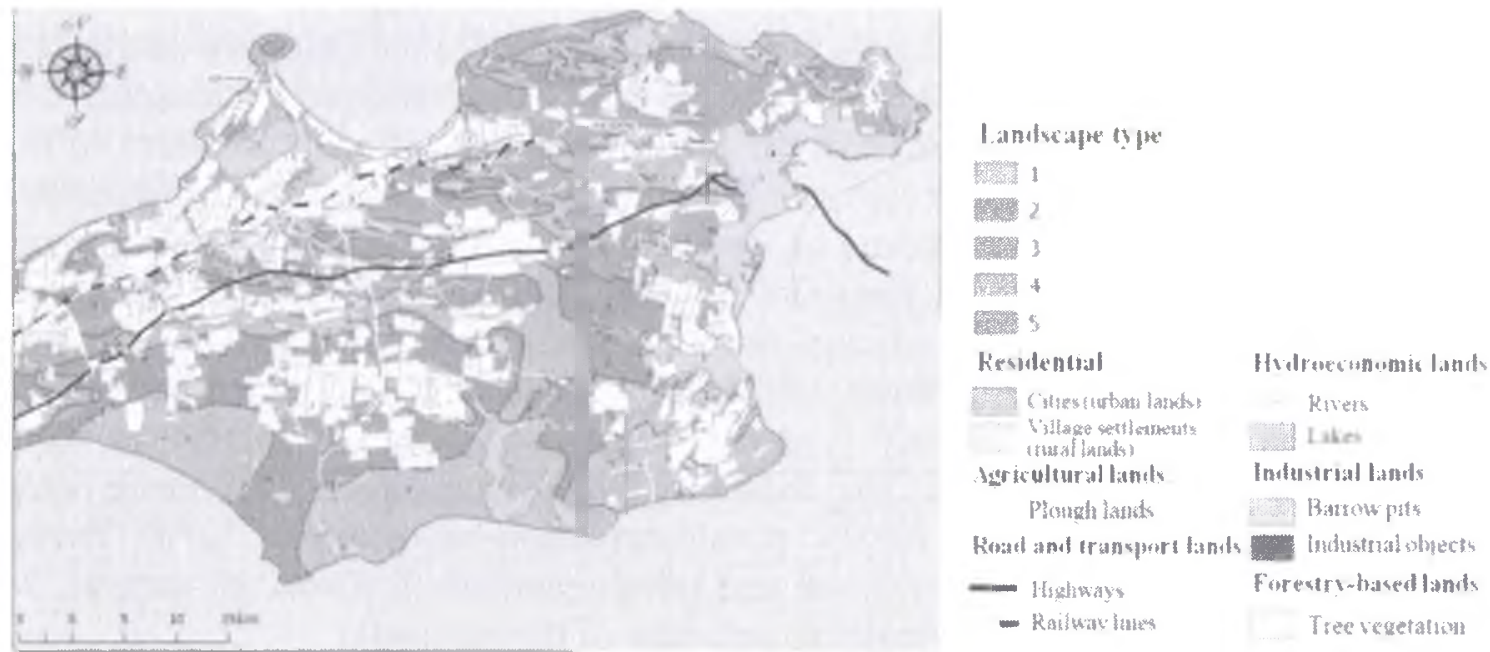

Figure 4. Modern landscapes of Kerch Peninsula 
A map of the present-day Kerch Peninsula landscapes can be used for territorial plinning, including landscape one; it makes the basis for the development of other maps lor: ecological network, including specially protected areas and their buffer zones; lundscape and environmental restrictions; spatial distribution of monitoring points and vurious types of environmental management. This is a basic map for different usisessment systems and development of evaluation maps.

\section{CONCLUSIONS}

The present-day Kerch Peninsula landscapes are presented as integrative geosystems where natural and economic subsystems are inseparably connected. An analysis of mininsula landscapes component structure (geological structure, relief, climate, water, soil, flora and fauna) shows that there are prerequisites for a large number of combinations of biotic and abiotic factors, which is reflected in the complex landscape structure. The complex structure of the Kerch Peninsula landscapes has been determined through the selection of landscape levels, landscape zones and landscape areas. A characteristic description of the current peninsula economy as an economic subsystem has showed that it is important to take into account natural prerequisites for the lormation of effective and environmentally balanced natural and economic territorial systems. The modern landscapes of the Peninsula show unity of natural and economic components, which using the means of cartography were shown by overlaying the maps of the natural and economic subsystems. The map of present-day landscapes can be used for territorial planning, including the landscape one; it can be also taken as a basis for expert activities on sustainable nature management, development of other thematic maps and evaluation maps such as assessment of the anthropogenic transformation degree of the landscape ecological condition of the territory and others.

\section{ACKNOWLEDGEMENTS}

This research was carried out with the support of the Program for the Development of the Crimean Federal V.I. Vernadsky University for 2015-2024 during the project "Academic Mobility Network "GIS-Landscape - Technologies and techniques for the formation of geoportals of present-day landscapes of regions" in 2017 and partially supported by the V.I. Vernadsky Crimean Federal University Development Program for 2015-2024 (VG05/18 "Landscape planning of plain Crimea for the sustainable development of the territory" in 2018-2019).

\section{REFERENCES}

[1] Zubarev, V., Smekalov, S., Yartsev, S. Materials for the ancient landscape reconstruction in the Adzhiel landscape compartment in the Eastern Crimea (the first stage research results). Journal of Archaeological Science: Reports, 2018. https://doi.org/10.1016/j.jasrep.2018.02.006

[2] Crimea: The History of Interaction between Man and Nature. Lisetskii, F.N. (Editor). Nova Science Publishers, 2019.

[3] Chendev, Yu.G. Soils in the area of the antique town of Kitei (the Crimean Peninsula). Eurasian Soil Science, 38 (8), pp 834-842, 2005.

[4] Lisetskii, F.N., Ergina, E.I. Soil development on the Crimean Peninsula in the late Holocene. Eurasian Soil Science, 43 (6), pp 601-613, 2010. 
[5] Lisetskii, F.N. Soil reproduction in steppe ecosystems of different ages Contemporary Problems of Ecology, 5 (6), pp 580-588, 2012.

[6] Molev, E.A., Korzhenkov, A.M., Ovsyuchenko, A.N., Larkov, A.S. Potentinl traces of earthquakes in the ancient city of Kytaia, Kerch Peninsula, Crimen Geodesy and Geodynamics, 2018.

[7] Sokol, E.V., Kokh, S.N., Kozmenko, O.A., Lavrushin, V.Y., Kikvadze, O.^ Mud volcanoes as important pathway for trace element input to the environment Case study from the Kerch-Taman province, northern Black Sea. International Multidisciplinary Scientific GeoConference Surveying Geology and Mininy. Ecology Management, SGEM, 18 (1.1), pp 307-322, 2018.

[8] Dragan N.A. Crimea soil resources. Dolya, Simferopol, 2004.

[9] Kvitnytskaya, A.A. Structure of flora of Kerchensky peninsula. Bull. of the Stato Nikit. Botan. Gard., 103, pp 11-17, 2011.

[10] Bagrikova, N.A. Analysis of adventive fraction of flora of natural reserves of the Kerch peninsula (Crimea). Optimization and Protection of Ecosystems, 4 (72). pp 3-9, 2011.

[11] Pashchenko, V.M. Steppe zone. In: Nature of the Ukrainian SSR. Landscapes, physiographic zoning, pp 122-179, 1985.

[12] Pozachenyuk, E.A Landscape diversity of Crimea. Scientific Notes of V.I. Vernadsky Crimean Federal University, l (4), pp 37-50, 2015.

[13] Atlas: Autonomous Republic of Crimea. Bagrov, N.V., Rudenko, L.G. (Editors), 2003.

[14] Korzhenevsky, V.V., Korzhenevskaya, Yu.V., Kvitnitskaya, A.A. Natural reserves of the Kerch Peninsula : problems and prospects. Bulletin of the University of Tambov. Series: Natural and Technical Sciences, 22 (5-1), pp 930934, 2017. 